\title{
FSH influences follicle viability, oestradiol biosynthesis and ovulation rate in Romney ewes
}

\author{
K. P. McNatty, N. Hudson, M. Gibb, K. Ball, K. M. Henderson, \\ D. A. Heath, S. Lun and L. E. Kieboom
}

Wallaceville Animal Research Centre, Research Division, Ministry of Agriculture and Fisheries, Private Bag, Upper Hutt, New Zealand

\begin{abstract}
Summary. Injection of steroid-free bovine follicular fluid (bFF; $2 \times 5 \mathrm{ml} \mathrm{s.c.} 12 \mathrm{~h}$ apart) into anoestrous ewes lowered plasma FSH concentrations by $70 \%$ and after $24 \mathrm{~h}$ had significantly $(P<0.01)$ reduced the number of non-atretic follicles $(\geqslant 1 \mathrm{~mm}$ diam.) without influencing the total number of follicles ( $\geqslant 1 \mathrm{~mm}$ diam.) compared to untreated controls. Hourly injections of FSH (10 $\mu$ g i.v. NIH-FSH-S12) for $24 \mathrm{~h}$ did not influence the number of non-atretic follicles but did negate the inhibitory effects of bFF on follicular viability. Hourly injections of FSH $(50 \mu \mathrm{g}$ i.v., NIH-FSH-S12) + $\mathrm{bFF}$ treatment for $24 \mathrm{~h}$ significantly increased the total number of non-atretic follicles, and particularly the number of medium to large non-atretic follicles ( $\geqslant 3 \mathrm{~mm}$ diam.) compared to the untreated controls (both $P<0.01$ ). The $10 \mu \mathrm{g}$ FSH regimen (without bFF) significantly increased aromatase activity in granulosa cells from large ( $\geqslant 5 \mathrm{~mm}$ diam.; $P<0.01$ ) but not medium (3-4.5 mm diam.) or small ( $1-2.5 \mathrm{~mm}$ diam.) follicles compared to controls. The $10 \mu \mathrm{g}$ FSH $+\mathrm{bFF}$ regimen had no effect on granulosa-cell aromatase activity compared to the controls. However, the $50 \mu \mathrm{g}$ FSH plus bFF regimen increased the aromatase activity of granulosa cells from large, medium and small non-atretic follicles $2 \cdot 6-, 8 \cdot 3-$ and $\geqslant 11$-fold respectively compared to that in the control cells.
\end{abstract}

Ewes $(\mathrm{N}=11)$ that ovulated 2 follicles had significantly higher plasma FSH concentrations from 48 to $24 \mathrm{~h}$ and 24 to $0 \mathrm{~h}$ before the onset of a cloprostenol-induced follicular phase (both $P<0.01)$ than in the ewes $(\mathrm{N}=12)$ that subsequently ovulated one follicle. Hourly FSH treatment (1.6 $\mathrm{g}$ i.v., NIAMDD-FSH-S15) for $24 \mathrm{~h}$ but not for any $6 \mathrm{~h}$ intervals between 48 and $24 \mathrm{~h}$ or 24 and $0 \mathrm{~h}$ before a cloprostenol-induced luteolysis also resulted in significant increases $(P<0.05)$ in the number of ewes with 2 ovulations.

We conclude that (1) the number of non-atretic antral follicles in sheep ovaries is influenced by plasma FSH concentrations; (2) the level of follicular oestradiol biosynthesis can be enhanced by FSH treatment; and (3) sustained elevations of plasma FSH concentrations for $24 \mathrm{~h}$ but not $6 \mathrm{~h}$ within $48 \mathrm{~h}$ of the onset of luteolysis significantly enhances the ovulation rate in Romney ewes.

\section{Introduction}

Follicle-stimulating hormone (FSH) is believed to act specifically on granulosa cells to influence the viability of ovarian follicles and ultimately their ability to ovulate (Hirshfield, 1979; Richards, 1980; Peters \& McNatty, 1981; Monniaux, Chupin \& Saumande, 1983). The viability of an antral follicle may be assessed from its morphological characteristics and/or the ability of its granulosa cells to synthesize oestradiol-17ß (Byskov, 1978; McNatty, 1981; Tsafriri \& Braw, 1984; McNatty et al., 1985). Pregnant mares' serum gonadotrophin (PMSG) is known to influence the proportions of 
atretic and non-atretic follicles in rats and sheep without altering the total antral follicle population (Peters, Byskov, Himelstein-Braw \& Faber, 1975; Dott, Hay, Cran \& Moor, 1979; Braw \& Tsafriri, 1980; McNatty et al., 1982). However, it is not known whether the 'atresia-preventing' or 'atresiareversing' effects of PMSG are due solely to its FSH-like properties or to those of both LH and FSH (Monniaux et al., 1983). In rats, FSH is known to induce/activate oestrogen-synthetase (aromatase) activity in granulosa cells (Dorrington, Moon \& Armstrong, 1975), but in sheep it is not known whether FSH influences granulosa-cell aromatase activity directly by modulating enzyme activity or indirectly by influencing follicle viability (McNatty, 1981).

FSH treatment of animals of various species increases the ovulation rate (Greenwald, 1962; Laster, 1973; Elsden, Nelson \& Seidel, 1978; Wright, Bondioli, Grammer, Kuzan \& Menino, 1981; Armstrong \& Evans, 1983), whereas low concentrations of plasma FSH resulting from a clinical disturbance, oestrogen implants or follicular fluid treatment leads to a short-term delay in ovulation, anovulation or inadequate luteal function (Ross et al., 1970; Stouffer, Coensgen, di Zerega \& Hodgen, 1981; Zeleznik, 1981; McNeilly, 1984). Ewes and cows that ovulate 2 or more follicles might therefore do so because they have higher FSH concentrations than do animals that ovulate only one follicle. However, in sheep, the evidence for a positive relationship between endogenous FSH concentrations and ovulation rate has been equivocal (Bindon, Blanc, Pelletier, Terqui \& Thimonier, 1979; Scaramuzzi \& Radford, 1983; Lahlou-Kassi, Schams \& Glatzel, 1984).

The aim of this study on Romney ewes was to examine the temporal relationships between FSH concentrations in plasma and follicle viability, granulosa-cell aromatase activity and ovulation rate.

\section{Materials and Methods}

The animals in this study were 2.5- to 3.5-year-old parous Romney ewes.

Experiment $I$ was designed to examine the effects of lowering or raising the plasma FSH concentrations on follicle viability and granulosa-cell aromatase activity. In Romney ewes, the levels of granulosa-cell aromatase activity do not differ for a given follicle size during the oestrous cycle or anoestrus (McNatty et al., 1984). However, during anoestrus, the ovarian follicle population ( $\geqslant 1 \mathrm{~mm}$ diam.) is approximately 2 -fold higher than that during the oestrous cycle. We therefore reasoned that plasma FSH effects on ovarian follicle viability would more easily be observed during anoestrus. Accordingly, anoestrous ewes $(\mathrm{N}=28)$ were injected with saline $(0.9 \% \mathrm{w} / \mathrm{v} \mathrm{NaCl}$; $\mathrm{N}=8$ ), steroid-free bovine follicular fluid ( $N=6$; WA batch $\mathrm{V}, \mathrm{bFF} ; 2$ injections of $5 \mathrm{ml} \mathrm{s.c.} 12 \mathrm{~h}$ apart), ovine FSH $(\mathrm{N}=6 ; 10 \mu \mathrm{g}$ NIH-FSH-S12 (biopotency $=1.25 \mathrm{U} / \mathrm{mg} ; 1 \mathrm{U}=1 \mathrm{mg} \mathrm{NIH}$ FSH-S1) i.v. once per $\mathrm{h}$ for $24 \mathrm{~h}$ ), ovine FSH ( $=4 ; 10 \mu \mathrm{g}$ NIH-FSH-S12 injected as above) plus $\mathrm{bFF}$ (injected as above), or ovine FSH ( $=4,50 \mu \mathrm{g} \mathrm{NIH-FSH-S12} \mathrm{injected} \mathrm{at} \mathrm{hourly} \mathrm{intervals} \mathrm{as}$ above) plus bFF injected at 12-h intervals (as above). The purpose of injecting bFF was to lower the FSH concentrations in blood (McNeilly, 1984). The method for removing steroids from bFF was identical to that described by Henderson \& Franchimont (1981). The ovaries of all the above animals were excised for further study $24 \mathrm{~h}$ after the start of treatment. In an additional study to ascertain the influence of bFF (WA batch V; $2 \times 5 \mathrm{ml}$ injections s.c. $12 \mathrm{~h}$ apart) on FSH concentrations, blood samples were taken hourly from 16 anoestrous ewes ( 8 controls, 8 treated animals, $2.5 \mathrm{ml} \mathrm{blood} / \mathrm{sample}$ ) for $6 \mathrm{~h}$ before the first bFF injection and every hour thereafter for $24 \mathrm{~h}$.

Experiment 2 was designed to compare plasma FSH concentrations in ewes with two and one

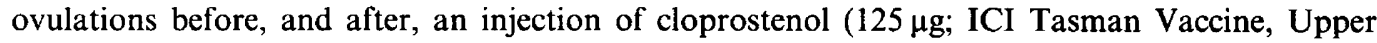
Hutt, N.Z.) on Days 8-10 of the oestrous cycle. On the day before blood sampling began, 44 ewes were penned indoors and each was fitted with an intrajugular cannula. When blood sampling began, the animals were bled $(2.5 \mathrm{ml})$ through the jugular cannulae, once every hour for 120 consecutive hours. Cloprostenol was injected into all ewes after $72 \mathrm{~h}$ and oestrous activity was recorded in all ewes by using 2 vasectomized Romney rams fitted with marking harnesses which were 
introduced to the ewes $102 \cdot 5 \mathrm{~h}$ after blood sampling began. At the end of the intensive blood sampling schedule, all animals were sent out to pasture and bled once daily for 21 days. After 7 days at pasture all animals were subjected to laparoscopy to determine their ovulation rates. Eleven animals had 2 corpora lutea (CL), 30 had $1 \mathrm{CL}$ and 3 had no visible CL. The blood samples from 12 of the animals with a single CL and all animals with 2 CL were retained for a study of FSH concentrations in blood. The use of only 12 of the animals with 1 CL was due to the limited amount of FSH antiserum.

Experiment 3. In Exp. 3, luteal phase (Days 7-10) ewes were injected with FSH (NIAMDDFSH-S1 5 (biological potency $20 \mathrm{U} / \mathrm{mg} ; 1 \mathrm{U}=1 \mathrm{mg} \mathrm{NIH-FSH-S1}$ ), $1.6 \mu \mathrm{g}$ i.v. once per $\mathrm{h}$ ) for 6 or $24 \mathrm{~h}$ before or after an injection of cloprostenol $(125 \mu \mathrm{g}$ i.m.) to induce ovulation. The different FSH preparation in Exp. 3 from that used in Exp. 1 was determined by the availability of materials from the National Institute of Arthritis, Metabolism and Digestive Diseases, U.S.A. In the 6-h FSH injection regimen, there were 10 control and 10 treated ewes in each 6 -h time frame from $72 \mathrm{~h}$ before to $24 \mathrm{~h}$ after cloprostenol treatment. In the 24-h FSH treatment regimen there were 15 control and 15 treated ewes covering the 24 -h time frames -72 to $-48,-48$ to $-24,-24$ to 0 and 0 to $+24 \mathrm{~h}$ from cloprostenol injection (given at time 0 ). All ewes were subjected to laparoscopy 6-12 days after cloprostenol injection. During the experimental period, the animals were penned indoors in the absence of a ram. To determine FSH concentrations before and after FSH treatment, 10 of the above animals injected with FSH hourly for $24 \mathrm{~h}$ were blood sampled by venepuncture before the first FSH injection, at 1-h after the first injection, and again at 10-min intervals until $1 \mathrm{~h}$ after the second injection.

The potency of the NIH-FSH-S15 preparation (oFSH) and that of a human FSH preparation (NIAMDD-FSH-2; hFSH) was assessed by measuring their ability to stimulate adenosine cyclic 3', 5'-monophosphate (cAMP) synthesis from pools of granulosa cells recovered from non-atretic follicles ( $\geqslant 3 \mathrm{~mm}$ diam.), atretic follicles $(\geqslant 3 \mathrm{~mm}$ diam.) and from a mixture of atretic and non-atretic follicles $(1-2.5 \mathrm{~mm}$ diam.). The granulosa cells were recovered from 75 follicles ( $\geqslant 1 \mathrm{~mm}$ diam.) of 2 ewes on Day 10 of the oestrous cycle.

All the heparinized blood samples from Exps 1, 2 and 3 were centrifuged $\left(4000 \mathrm{~g}\right.$ at $18-20^{\circ} \mathrm{C}$ for $20 \mathrm{~min}$ ) within $15 \mathrm{~min}$ of collection and the plasma recovered and frozen to $-20^{\circ} \mathrm{C}$ until hormone analysis.

Ovarian studies. Excised ovaries were weighed and their gross morphology recorded. All individual follicles ( $\geqslant 1 \mathrm{~mm}$ diam.) were dissected free of extraneous tissue under a stereomicroscope and their diameters recorded to the nearest $0.5 \mathrm{~mm}$. A small slit was made in the follicle wall to allow the antral fluid to escape into a Petri dish whence it was aspirated through a finely drawnout Pasteur pipette, taking care not to remove clumps or sheets of granulosa cells. The fluid was then discarded. The granulosa cells were recovered and counted by haemocytometer. During the recovery of follicular fluid or granulosa cells, the oocyte was also isolated and subjectively assessed as healthy or degenerate as previously described (McNatty et al., 1985). To help classify follicles as non-atretic or atretic, the presence or absence of thecal blood capillaries (at $\times 10$ magnification) and of debris in follicular fluid was noted. In addition, after removal of the granulosa cells, the colour of the theca interna (i.e. red, pink or white) was recorded. For the purpose of this study a healthy follicle was defined as one with: (a) visible thecal blood capillaries, (b) follicular fluid devoid of debris, (c) an apparently healthy oocyte, (d) a pink- to red-coloured theca interna, and (e) $>25 \%$ of the maximum number of granulosa cells for a given follicle size (McNatty et al., 1985). Conversely, an atretic follicle was one to which any of these criteria did not apply.

Granulosa cell aromatase assay. Pools of granulosa cells from follicles at similar stages of development ( 3 experiments) were collected into Medium 199 containing sodium bicarbonate $(0.85 \mathrm{~g} / 1)$, Earle's salts, L-glutamine $(0 \cdot 10 \mathrm{~g} / \mathrm{l})$, Hepes buffer $(20 \mathrm{~mm})$ and $1 \% \mathrm{BSA}(\mathrm{w} / \mathrm{v})$ (Medium $\mathrm{A}, \mathrm{ph}=7 \cdot 4)$. They were washed and resuspended in Medium A so that the final cell concentration was $6-60 \times 10^{4}$ granulosa cells $/ \mathrm{ml} ; 0.5 \mathrm{ml}$ aliquants of these cell suspensions were placed in 
$10 \mathrm{~mm} \times 75 \mathrm{~mm}$ plastic tubes containing $0.5 \mathrm{ml}$ of a solution of $2000 \mathrm{ng}$ testosterone $/ \mathrm{ml}$. The cell suspensions were gassed with $5 \% \mathrm{CO}_{2}$ in air, stoppered and then incubated for $3 \mathrm{~h}$ in a shaking water bath at $37^{\circ} \mathrm{C}$. At the end of the incubation, the tubes containing medium plus cells were frozen at $-20^{\circ} \mathrm{C}$. Subsequently, the contents of the tubes were thawed, centrifuged and the supernatants assayed for oestradiol-17 $\beta$.

Granulosa cell incubations for cAMP measurements. The granulosa cells from non-atretic or atretic follicles of $\geqslant 3 \mathrm{~mm}$ diameter or from a mixture of non-atretic and atretic follicles of 1-2.5 mm diameter in Medium A were centrifuged and the pellet resuspended in Dulbecco's phosphate-buffered saline solution (KC Biological Inc., Lenexa, Kansas, U.S.A.) plus 0.1\% BSA (Medium B) to a concentration of $2-5 \times 10^{5}$ cells $/ \mathrm{ml}$. Aliquants $(0.5 \mathrm{ml})$ of these cells were added to $10 \mathrm{~mm} \times 75 \mathrm{~mm}$ test-tubes containing $0.5 \mathrm{ml}$ Medium B with $0,1,10,100,1000$ or $10000 \mathrm{ng}$ of ovine FSH (NIH-FSH-S15) or human FSH (NIAMDD-hFSH-2; biopotency 3926 i.u. FSH/mg, reference preparation WHO FSH/LH 70/45). The tubes were capped and then incubated for $1 \mathrm{~h}$ in a shaking water bath at $37^{\circ} \mathrm{C}$. All assays were performed in triplicate with the appropriate controls. At the end of the incubation, the assay tubes were plunged into boiling water for $20 \mathrm{~min}$ and then snap frozen to $-70^{\circ} \mathrm{C}$. Subsequently, the contents of the tubes were thawed and assayed for cAMP.

Assays. The heterologous radioimmunoassay for ovine FSH was identical to that described by McNatty et al. (1984). Briefly, the FSH standard was NIH-FSH-S11 (1.15 U/mg), a Papkoff ovine FSH preparation G4-150C (Dr H. Papkoff, Hormone Research Laboratory, University of California, San Francisco, U.S.A.) was used as the iodinated tracer, and the antibody was a rabbit anti-human FSH (M-94) supplied by Dr W. Butt (Women's Hospital, Birmingham, U.K.). The mean within- and between-assay coefficients of variation were 5.6 and $8.5 \%$ respectively over the working assay range of $2-30 \mathrm{ng}$ per tube.

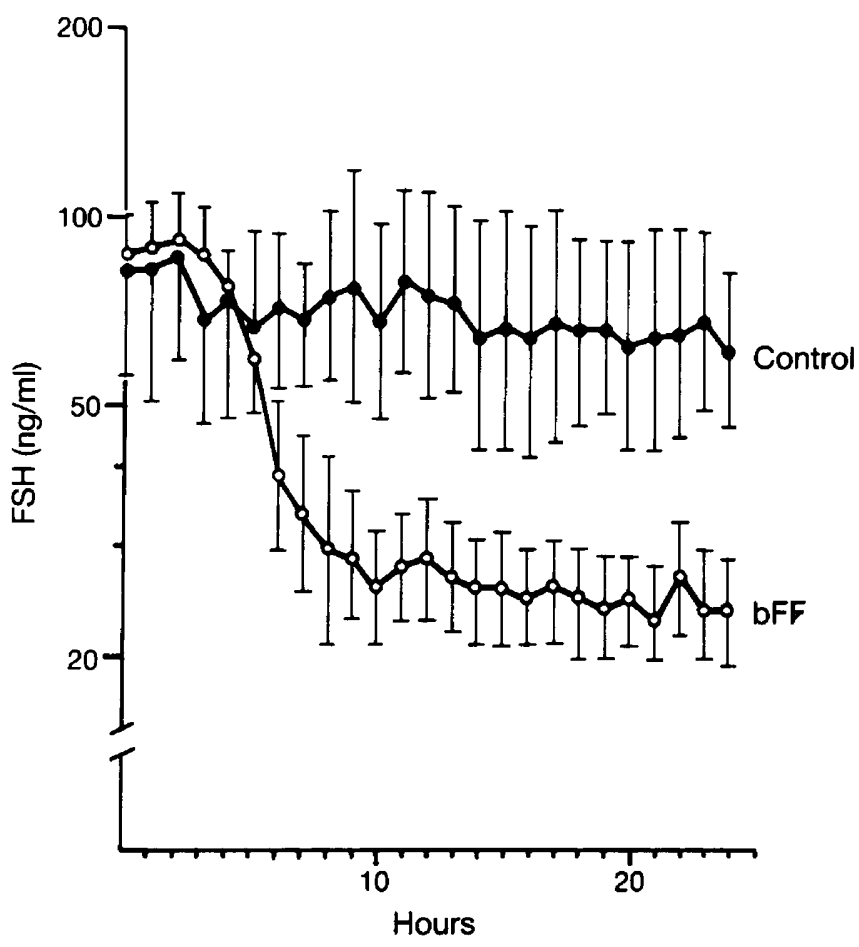

Text-fig. 1. Effect of steroid-free bovine follicular fluid (bFF), $5 \mathrm{ml} \mathrm{s.c.} \mathrm{at} \mathrm{time} 0$ and $12 \mathrm{~h}$ on plasma FSH concentrations in anoestrous Romney ewes. Results are expressed as geometric means and $95 \%$ confidence limits (i.e. vertical bars; 8 controls, 8 treated ewes). 
Progesterone in plasma and oestradiol- $17 \beta$ in culture medium were measured by radioimmunoassay procedures described in detail elsewhere (McNatty et al., 1982, 1984). For progesterone which was extracted from plasma with $2 \times 5$ volumes of petroleum ether (boiling range $40-50^{\circ}$ ), the antiserum used was WA-26 (see McNatty et al., 1984, for details concerning cross-reactivity) and the minimal detectable quantity in plasma was $200 \mathrm{pg} / \mathrm{ml}$.

Oestradiol-17 $\beta$ in Medium A (the aromatase assay solution) was measured directly, without extraction. The antiserum used was WA-27 (McNatty et al., 1984) and the minimum detectable quantity of oestradiol- $17 \beta$ in $0.1 \mathrm{ml}$ Medium A was $5 \mathrm{pg}$.

The intra- and inter-assay coefficients of variation for the above steroids were $<10 \%$.

The media $(0 \cdot 1 \mathrm{ml})$ were assayed directly, without extraction, for cAMP by radioimmunoassay using the New England Nuclear ${ }^{125}$ I-labelled cAMP radioimmunoassay kit; the acetylation step was included. The results were expressed as pmol cAMP $/ 10^{6}$ granulosa cells. All samples were measured in the same assay; the intra-assay coefficient of variation was $8 \%$.

Analysis of results. To compare FSH concentrations in animals that subsequently ovulated 1 or 2 follicles (i.e. Exp. 2), a log-transformed mean FSH concentration for each animal was determined for each of the following time frames: -72 to $-48,-48$ to $-24,-24$ to 0 and 0 to $+24 \mathrm{~h}$ from cloprostenol injection. Thereafter, for each of the above time frames, the overall mean for animals that had $1 \mathrm{CL}$ was compared with that for animals that had $2 \mathrm{CL}$ by an unpaired two-tailed Student's $t$ test.

The numbers of animals with a single or a double ovulation after exogenous FSH treatment (Exp. 3) were compared to the corresponding numbers in the untreated controls by $\chi^{2}$ analysis; in these experiments none of the animals ovulated more than 2 follicles.

The effects of bFF and/or FSH inoculation in sheep on follicle number, follicle viability and aromatase activity were evaluated by analysis of variance.

\section{Results}

Effect of FSH and/or steroid-free bovine follicular fluid (bFF) treatment on plasma FSH concentrations, follicle viability and granulosa-cell aromatase activity (Exp. 1)

The FSH concentrations in anoestrous ewes injected with bFF or saline $(2 \times 5 \mathrm{ml}$ injections s.c. $12 \mathrm{~h}$ apart) are shown in Text-fig. 1. Treatment with bFF caused a progressive reduction in the geometric mean $(95 \%$ confidence limits in parentheses) plasma FSH concentrations from 88 ( 76 , 100) $\mathrm{ng} / \mathrm{ml}$ at the start of treatment to $26(21,32) \mathrm{ng} / \mathrm{ml}$ some $10 \mathrm{~h}$ later $(P<0.01)$; the latter concentrations once reached were maintained for at least $14 \mathrm{~h}$.

The effects of bFF and/or FSH treatment on the number of non-atretic follicles and their distribution with respect to follicular diameter are shown in Table 1. There was no effect of any of the treatments on the total number of follicles present in each ewe. Treatment with bFF significantly reduced the number of medium to large ( $\geqslant 3 \mathrm{~mm}$ diam.) non-atretic follicles. Treatment of ewes with the $10 \mu \mathrm{g} \mathrm{FSH}$ regimen alone had no effect on the numbers of non-atretic follicles, but the $10 \mu \mathrm{g} \mathrm{FSH}+\mathrm{bFF}$ regimen neutralized the suppressive effects observed in ewes treated with bFF alone. Treatment of ewes with a $50 \mu \mathrm{g} \mathrm{FSH} \mathrm{+} \mathrm{bFF} \mathrm{regimen} \mathrm{significantly} \mathrm{increased} \mathrm{the} \mathrm{number} \mathrm{of}$ non-atretic follicles and the number of medium to large non-atretic follicles ( $\geqslant 3 \mathrm{~mm}$ diam.).

The effects of bFF and/or FSH inoculation on aromatase activity in granulosa cells are summarized in Table 2. The $10 \mu \mathrm{g}$ FSH regimen increased aromatase activity in cells from follicles of $\geqslant 5 \mathrm{~mm}$ diameter $4 \cdot 7$-fold compared to that in control ewes and $1 \cdot 8$-fold compared to that in ewes treated with bFF $+50 \mu \mathrm{g} \mathrm{FSH}$. In contrast, treatment with $10 \mu \mathrm{g}$ FSH had no stimulatory effect on aromatase activity in medium or small diameter follicles. Aromatase activity in cells from the ewes treated with $\mathrm{bFF}+10 \mu \mathrm{g}$ FSH was not significantly different from that in the control animals, but activity in cells from the $\mathrm{bFF}+50 \mu \mathrm{gSH}$-treated ewes was significantly different from that in the 
Table 1. Effect of steroid-free bovine follicular fluid (bFF) and/or FSH treatment in sheep on the number of non-atretic follicles and their distribution with respect to follicular diameter

\begin{tabular}{|c|c|c|c|c|c|}
\hline \multirow[b]{2}{*}{ Treatment } & \multirow{2}{*}{$\begin{array}{l}\text { No. } \\
\text { of } \\
\text { ewes }\end{array}$} & \multirow{2}{*}{$\begin{array}{c}\begin{array}{c}\text { Total no. of } \\
\text { follicles }\end{array} \\
(\geqslant 1 \mathrm{~mm} \text { diam. }) \\
\text { per ewe }\end{array}$} & \multirow{2}{*}{$\begin{array}{c}\text { No. of non- } \\
\text { atretic follicles } \\
(\geqslant 1 \text { mm diam. }) \\
\text { per ewe }\end{array}$} & \multicolumn{2}{|c|}{$\begin{array}{l}\text { No. of non-atretic follicles } \\
\text { with respect to follicular } \\
\text { diameter (mm) }\end{array}$} \\
\hline & & & & $\geqslant 3$ & $1-2 \cdot 5$ \\
\hline Control & 8 & $33 \cdot 5 \pm 3.6$ & $7 \cdot 3 \pm 0.7$ & $3 \cdot 3 \pm 0 \cdot 5$ & $4 \cdot 0 \pm 0.6$ \\
\hline bFF & 6 & $30.7 \pm 3.9$ & $* 1.5 \pm 0.5$ & $* 0.2 \pm 0.2$ & $1 \cdot 3 \pm 0.5$ \\
\hline $10 \mu \mathrm{g} \mathrm{FSH}$ & 6 & $29 \cdot 0 \pm 3.3$ & $8 \cdot 7 \pm 0.7$ & $2 \cdot 2 \pm 0.3$ & $6.5 \pm 0.6$ \\
\hline $\begin{array}{c}10 \mu \mathrm{g} \mathrm{FSH} \\
+\mathrm{bFF}\end{array}$ & 4 & $36 \cdot 2 \pm 4 \cdot 7$ & $7 \cdot 7 \pm 1 \cdot 5$ & $3.2 \pm 0.8$ & $4.5 \pm 0.9$ \\
\hline $\begin{array}{c}50 \mu \mathrm{gFSH} \\
+\mathrm{bFF}\end{array}$ & 4 & $39 \cdot 0 \pm 5 \cdot 3$ & $* 23.8 \pm 3.7$ & $* 18 \cdot 3 \pm 3 \cdot 5$ & $5 \cdot 5 \pm 1 \cdot 1$ \\
\hline
\end{tabular}

Values are mean \pm s.e.m.

*Values significantly different from that of control $(P<0.01$; ANOVA).

Table 2. Effect of steroid-free bovine follicular fluid (bFF) and/or FSH treatment in sheep on aromatase activity (ng oestradiol- $17 \beta / 10^{6}$ granulosa cells $/ 3 \mathrm{~h}$ ) in granulosa cells from non-atretic follicles

\begin{tabular}{|c|c|c|c|}
\hline \multirow[b]{2}{*}{ Treatment } & \multicolumn{3}{|c|}{ Follicle diameter (mm) } \\
\hline & $\geqslant 5$ & $3-4 \cdot 5$ & $1-2 \cdot 5$ \\
\hline $\begin{array}{l}\text { Control } \\
\mathrm{bFF} \\
\mathrm{bFF}+10 \mu \mathrm{g} \mathrm{FSH} \\
\mathrm{bFF}+50 \mu \mathrm{g} \mathrm{FSH} \\
10 \mu \mathrm{gSH}\end{array}$ & $\begin{array}{c}5 \cdot 3 \pm 0 \cdot 3 \\
3 \cdot 4 \dagger \\
5 \cdot 6 \pm 0 \cdot 2 \\
14 \cdot 0 \pm 0 \cdot 6^{*} \\
25 \cdot 1 \pm 0 \cdot 6 \ddagger\end{array}$ & $\begin{array}{c}2 \cdot 9 \pm 0 \cdot 2 \\
- \\
3 \cdot 0 \pm 0 \cdot 3 \\
24 \cdot 2 \pm 3 \cdot 6^{*} \\
2 \cdot 6 \pm 0 \cdot 1\end{array}$ & $\begin{array}{c}\leqslant 0 \cdot 3 \\
\leqslant 0 \cdot 3 \\
\leqslant 0 \cdot 3 \\
3 \cdot 3 \pm 0 \cdot 3^{*} \\
\leqslant 0 \cdot 3\end{array}$ \\
\hline
\end{tabular}

Values are mean \pm s.e.m. for 3 follicles.

*Value significantly different from that of control $(P<0.01$; ANOVA).

$\dagger$ Data from only one follicle and was excluded from the ANOVA.

tValue significantly different from value of $\mathrm{bFF}+50 \mu \mathrm{g}$ FSH

$(P<0.01 ;$ ANOVA $)$.

control animals $(P<0.01)$ over all follicle diameters. Indeed, the activity in follicles of $3-4.5 \mathrm{~mm}$ diameter was similar to that observed in cells from follicles of $\geqslant 5 \mathrm{~mm}$ diameter from ewes treated with $10 \mu \mathrm{g} \mathrm{FSH.}$

\section{FSH concentrations in ewes with 1 or 2 ovulations (Exp. 2)}

These data are summarized in Text-fig. 2 . There were no significant differences in the geometric mean FSH concentrations between ewes that subsequently ovulated 1 or 2 follicles over the time frames -72 to $-48 \mathrm{~h}, 0$ to $+24 \mathrm{~h}$ and +24 to $+48 \mathrm{~h}$ from cloprostenol injection. However, over the time frames -48 to $-24 \mathrm{~h}$ and -24 to $0 \mathrm{~h}$ from cloprostenol injection, the respective geometric mean FSH concentrations in the ewes that subsequently ovulated 2 follicles were significantly higher than in those that ovulated 1 follicle (both $P<0.01$, unpaired Student's $t$ test). The overall geometric mean (and 95\% confidence limits) for the FSH concentrations at -48 to $-24 \mathrm{~h}$ was 105 $(102,107) \mathrm{ng} / \mathrm{ml}$ for ewes that subsequently had 2 CL compared to $74(72,77) \mathrm{ng} / \mathrm{ml}$ for the ewes that subsequently had $1 \mathrm{CL}$, whereas at -24 to $0 \mathrm{~h}$ from cloprostenol injection the FSH concen- 


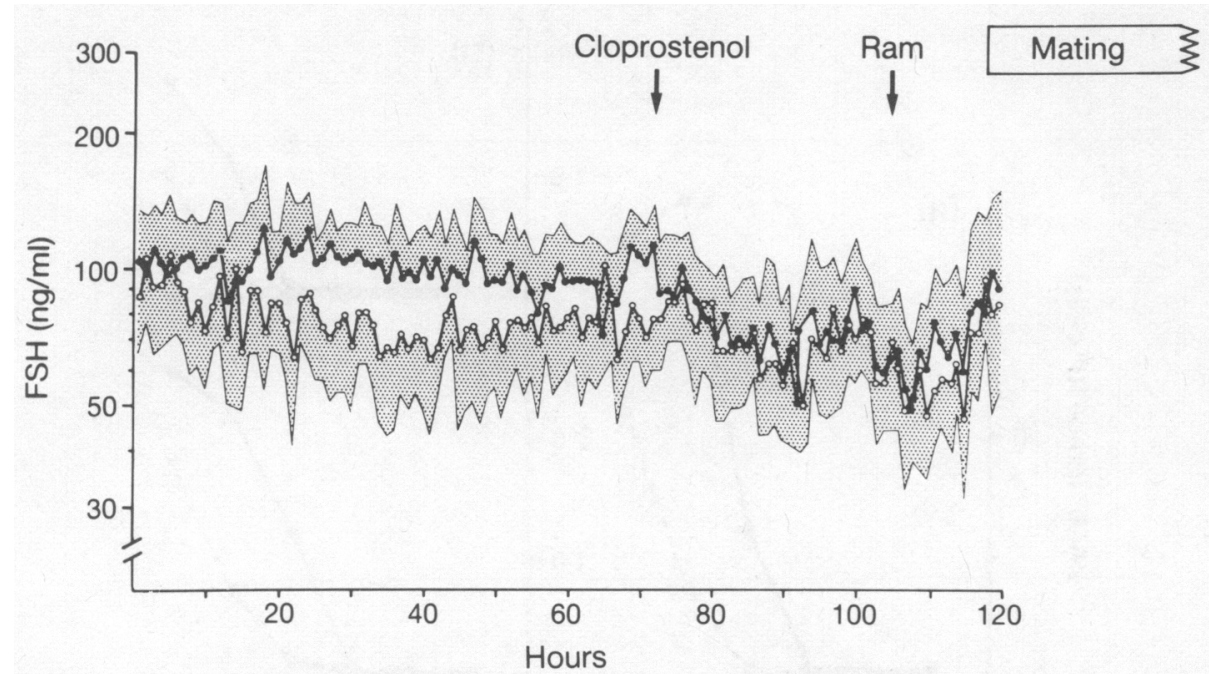

Text-fig. 2. Geometric mean concentrations of plasma FSH each hour for Romney ewes from $-72 \mathrm{~h}$ before until $48 \mathrm{~h}$ after cloprostenol injection $(125 \mu \mathrm{g}$ s.c.): -1 represents the results for animals $(\mathrm{N}=11)$ that subsequently formed 2 corpora lutea whereas $\mathrm{O}-\mathrm{O}$ represents the results for animals $(N=12)$ that subsequently formed only 1 corpus luteum. The vasectomized rams were introduced to the flock at $30.5 \mathrm{~h}$ and the matings occurred from 46 to $96 \mathrm{~h}$ after cloprostenol injection. Shaded areas $=95 \%$ confidence limits. For the sake of clarity only the upper or lower limits are shown although these are equidistant each side of the mean.

trations were $96(90,102)$ and $79(76,82) \mathrm{ng} / \mathrm{ml}$ for the ewes that subsequently had 2 and $1 \mathrm{CL}$ respectively.

In the cycle after cloprostenol injection all ewes had plasma progesterone concentrations $\geqslant 1 \mathrm{ng} / \mathrm{ml}$ by 5 days after mating and all were adjudged to have had normal CL since the progesterone concentrations were $\geqslant 1 \mathrm{ng} / \mathrm{ml}$ for at least 8 days of the cycle. No significant differences were noted in mean daily concentrations of progesterone between those with 1 or $2 \mathrm{CL}$.

\section{Effect of FSH treatment on granulosa-cell cAMP synthesis and ovulation rate (Exp. 3)}

The effects of different doses of ovine FSH (NIAMDD-FSH-S15) and human FSH (NIAMDD-hFSH-2) on stimulation of granulosa cell cAMP synthesis are shown in Text-fig. 3 . Doses of 1 and $10 \mu \mathrm{g}$ human $\mathrm{FSH} / \mathrm{ml}$ and $10 \mu \mathrm{g}$ ovine $\mathrm{FSH} / \mathrm{ml}$ stimulated granulosa-cell cAMP synthesis in all follicles. The $10 \mu \mathrm{g}$ dose of ovine FSH stimulated a cAMP response which was only $56-70 \%$ of that achieved with $10 \mu \mathrm{g}$ human FSH.

In the 10 ewes injected (i.v.) hourly with $1.6 \mu$ g ovine FSH (NIH-FSH-S15) and blood sampled before and during treatment (see 'Materials and Methods'), the geometric mean (and 95\% confidence limits) for the FSH concentrations before and during the first $2 \mathrm{~h}$ of treatment were 81 (59, $111)$ and $98(74,128) \mathrm{ng} / \mathrm{ml}$ respectively. The overall geometric mean FSH concentration during FSH supplementation was $121 \pm 3 \%$ of that before treatment.

There were no significant increases in the subsequent ovulation rates in treated compared to control animals when the treated ewes were injected with $1.6 \mu \mathrm{g}$ ovine FSH (NIAMDD-FSH-S15) once per $\mathrm{h}$ for $6 \mathrm{~h}$ over any of the consecutive 6-h time frames from $72 \mathrm{~h}$ before to $24 \mathrm{~h}$ after cloprostenol injection. However, when ewes were injected with $1 \cdot 5 \mu \mathrm{g}$ ovine FSH (NIAMDD-FSHS15) once per $\mathrm{h}$ for $24 \mathrm{~h}$, the subsequent mean ovulation rates in the FSH and control ewes over the time frames -72 to $-48 \mathrm{~h},-48$ to $-24 \mathrm{~h},-24$ to $0 \mathrm{~h}$ and 0 to $+24 \mathrm{~h}$ from cloprostenol injection were respectively: 1.00 and 1.07, 1.40 and 1.07; 1.47 and 1.07; and 1.27 and 1.07. In this study, 


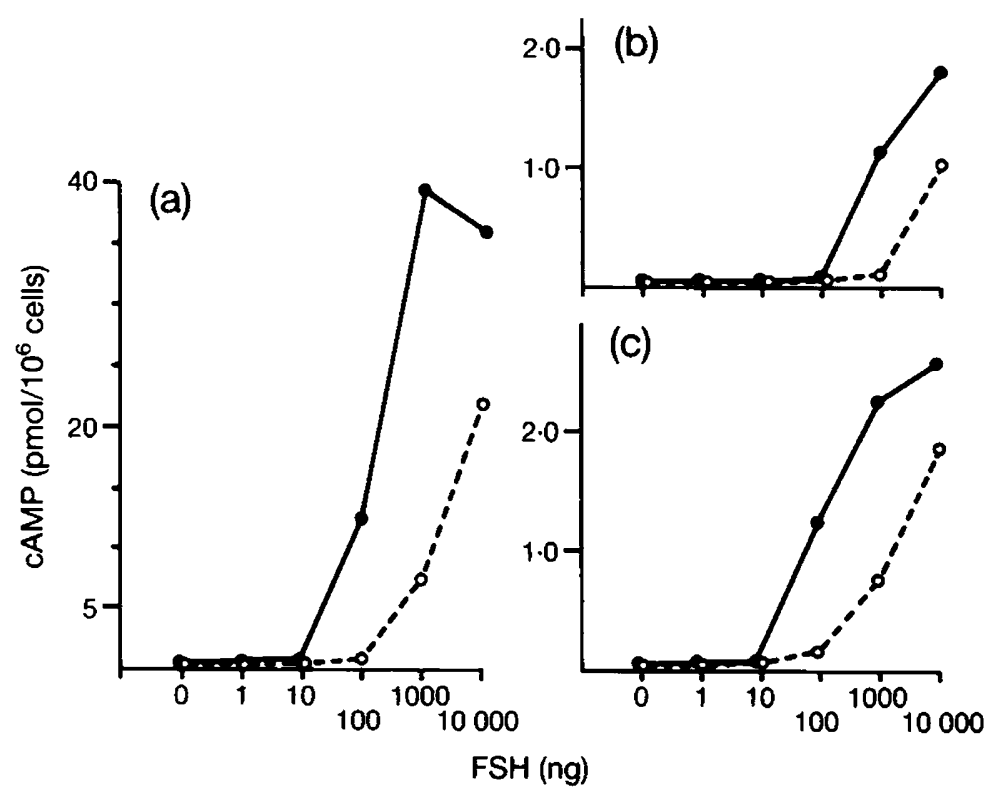

Text-fig. 3. Effect of different doses of human FSH (FSH (O---O; NIAMDD-FSH-S15) on stimulation of cAMP synthesis by ovine granulosa cells from non-atretic (a) or atretic (b) follicles of $\geq 3 \mathrm{~mm}$ diameter or (c) a mixture of non-atretic and atretic follicles of $1-2.5 \mathrm{~mm}$ diameter. Results are those from a single experiment (each point in triplicate) on pools of cells recovered from two pairs of sheep ovaries.

the treated and control ewes had 1 or $2 \mathrm{CL}$; no animals were identified with 3 or more CL. When the numbers of ewes with 1 or $2 \mathrm{CL}$ in the treated and control groups were compared by $\chi^{2}$ analysis, there was a significant effect of FSH treatment over the $24 \mathrm{~h}$ time frames of -48 to -24 or -24 to $0 \mathrm{~h}$ (both $P<0.05$ ) from PG injection but not for the other previously stated time frames.

\section{Discussion}

The results of this study show that the proportions of non-atretic and atretic follicles ( $\geqslant 1 \mathrm{~mm}$ diam.) in ovaries of anoestrous ewes are influenced markedly by the FSH concentrations in plasma. Compared to control ewes, treatment with bovine follicular fluid led to a $70 \%$ reduction in the plasma FSH concentrations and a significant reduction $(P<0.01)$ in the number of non-atretic follicles (i.e. from 22 to $5 \%$ ) without any alterations in the total number of antral follicles ( $\geqslant 1 \mathrm{~mm}$ diam.; Table 1). The hourly administration of ovine FSH (10 $\mu$ g i.v.; NIH-FSH-S12) for $24 \mathrm{~h}$ did not influence either the number of antral follicles ( $\geqslant 1 \mathrm{~mm}$ diam.) or the number of non-atretic follicles compared to the controls. Nevertheless, the $10 \mu \mathrm{g}$ FSH regimen completely negated the effects of bovine follicular fluid when the two treatments were given together; the numbers of non-atretic follicles were similar to those found in the controls. This finding suggests that the effects of bovine follicular fluid were due to a reduction in the plasma concentrations of FSH. The $50 \mu \mathrm{g}+\mathrm{bFF}$ regimen did not influence the total number of antral follicles ( $\geqslant 1 \mathrm{~mm} \mathrm{diam}$.) but it caused a significant $(P<0.01)$ increase in the number of non-atretic follicles $(\geqslant 1 \mathrm{~mm} \mathrm{diam}$.) compared to the untreated controls. This increase was due mainly to a $5 \cdot 5$-fold increase in the number 
of non-atretic $\geqslant 3 \mathrm{~mm}$ diameter follicles. The FSH treatment dose was presumably in excess of that required to offset the inhibitory effects of bovine follicular fluid and so the ovaries were subjected to a sustained (i.e. $24 \mathrm{~h}$ ) high level of FSH stimulation.

On the basis of the above results, it seems reasonable to suppose that follicle viability during the oestrous cycle is also influenced by the plasma concentrations of FSH. However, it cannot be assumed that follicle viability during the oestrous cycle would be influenced by FSH in precisely the same way as described in the present study on anoestrous Romney ewes. In this breed of ewe, there are significantly more $(P<0.01)$ antral follicles $(\geqslant 1 \mathrm{~mm}$ diam.) and significantly higher $(P<0.05)$ plasma FSH concentrations during anoestrus than during the luteal phase of the oestrous cycle (McNatty et al., 1984).

The present experiments show that FSH stimulates aromatase enzyme activity in ovine granulosa cells from non-atretic follicles as well as influencing follicle viability. The $10 \mu \mathrm{g} \mathrm{FSH}$ regimen caused a 5 -fold increase in aromatase activity in large ( $\geqslant 5 \mathrm{~mm}$ diam.) follicles compared to that from control ovaries. However, the $10 \mu \mathrm{g}$ FSH regimen had no effect on aromatase activity in medium ( $3-4.5 \mathrm{~mm}$ diam.) or small ( $\leqslant 2.5 \mathrm{~mm}$ diam.) follicles. The $10 \mu \mathrm{g} \mathrm{FSH}+$ bFF regimen resulted in granulosa cells having a level of aromatase activity identical to that in cells from control ovaries for all follicle diameters. In contrast, the $50 \mu \mathrm{g} \mathrm{FSH}+\mathrm{bFF}$ regimen caused a $2 \cdot 6$-fold, an $8 \cdot 3$-fold and $a \geqslant 11$-fold increase in granulosa-cell aromatase activity in cells from large, medium and small follicles, respectively, relative to that in cells from the corresponding controls. Presumably, the high levels of granulosa cell aromatase activity observed in this experiment was due to FSH treatment although some augmentation by effects of bovine follicular fluid cannot be ruled out (McLachlan, Colvin, Quigg, Burger \& Lee, 1984).

These results raised the possibility that the FSH concentrations in Romney ewes are normally insufficient to stimulate maximum oestrogen synthesis in developing follicles. For example, the level of granulosa-cell aromatase activity in large follicles ( $\geqslant 5 \mathrm{~mm}$ diam.) of anoestrous ewes (Table 2) was identical to that observed in preovulatory follicles during the breeding season (McNatty et al., 1984). However, this level of activity (i.e. $5 \cdot 3 \mathrm{ng}$ oestradiol $/ 10^{6} \mathrm{cells} / 3 \mathrm{~h}$ ) was only 0.2 times that produced by cells exposed to additional amounts of FSH in vivo (Table 2).

A major finding in the present study was that ewes ovulating 2 follicles had significantly higher $(P<0.01)$ plasma FSH concentrations from 48 to $24 \mathrm{~h}$ and 24 to $0 \mathrm{~h}$ before the onset of luteolysis than did ewes ovulating a single follicle. It seems that the $20-40 \%$ higher FSH concentrations before luteolysis in the sheep with twin ovulations (i.e. compared to those with a single ovulation) were causally related to the increase in ovulation rate. The hourly administration of ovine FSH (1.6 $\mu$ g i.v.; NIH-FSH-S15) increased the mean plasma FSH concentrations by $\sim 20 \%(P<0.01)$ and this FSH regimen over the 24-h time frames of 48 to $24 \mathrm{~h}$ or 24 to $0 \mathrm{~h}$ before luteolysis also led to a significant increase $(P<0.05)$ in the number of Romney ewes with twin ovulations. This increased frequency of twin ovulations after supplementary ovine FSH treatment was achieved under a dose regimen which was probably submaximal at the level of the granulosa cells. For example, the response of granulosa cells to $1.6 \mu$ g ovine FSH (NIH-FSH-S15) in terms of cAMP production in vitro was $\leqslant 50 \%$ of that attainable with human FSH (NIAMDD-hFSH-2). Also, the exogenous ovine FSH regimen was effective when administered for $24 \mathrm{~h}$ but not when administered for only $6 \mathrm{~h}$. These findings suggest that during the $6 \mathrm{~h}$ treatment regimen the dose of ovine FSH may have been too low and/or that the granulosa cells were not exposed to the additional FSH for a sufficient period of time. The latter is a possibility because of the time required for proteins to traverse to the granulosa cells from the peripheral circulation (Cran, Moor \& Hay, 1976). For example, the time delay between an elevation of immunoreactive FSH and/or LH in plasma and a corresponding increase in follicular fluid was about $4 \mathrm{~h}(\mathrm{McNatty}$, Dobson, Gibb, Kieboom \& Thurley, 1981; Dieleman, Bevers, Poortman \& van Tol, 1983).

The administration of PMSG (500 i.u.) simultaneously with cloprostenol is known to enhance ovulation rates in Romney ewes (Gibb, Thurley \& McNatty, 1981; McNatty et al., 1982). However, hourly injections of ovine FSH (1.6 $\mathrm{g}$ NIAMDD-FSH-S15 i.v.) or gonadotrophin-releasing 
hormone ( $500 \mathrm{ng}$ i.v.; data not shown) for $24 \mathrm{~h}$ from the onset of luteolysis failed to increase the ovulation rate in Romney ewes. Perhaps the difference in effectiveness between the three treatments was due to the longer half-life of PMSG than that of FSH and LH in vivo (Schams et al., 1978), although differences in dose rates cannot be ruled out.

We thank the National Institute of Arthritis, Metabolism and Digestive Diseases, U.S.A., for the generous supply of ovine and human FSH; Dr H. Papkoff, San Francisco, U.S.A., for the ovine FSH preparation; Dr W. Butt, Birmingham, U.K., for the FSH antiserum; Dr D. Thurley, Mrs J. Fannin, Mr P. Smith and Mrs J. McDiarmid for assistance with blood sampling and laparoscopy; and Mrs P. Cattermole for typing the manuscript.

\section{References}

Armstrong, D.T. \& Evans, G. (1983) Factors influencing success of embryo transfer in sheep and goats. Theriogenology 19, 31-42.

Bindon, B.M., Blanc, M.R., Pelletier, J., Terqui, M. \& Thimonier, J. (1979) Periovulatory gonadotrophin and ovarian steroid patterns in sheep of breeds with differing fecundity. J. Reprod. Fert. 55, $15-25$.

Braw, R. \& Tsafriri, H. (1980) Effect of PMSG on follicular atresia in the immature rat ovary. $J$. Reprod. Fert. 59, 267-272.

Byskov, A.G. (1978) Follicular atresia. In The Vertebrate Ovary, pp. 533-562. Ed. R. E. Jones. Plenum Press, New York.

Cran, D.G., Moor, R.M. \& Hay, M.F. (1976) Permeability of ovarian follicles to electron-dense macromolecules. Acta endocr., Copenh. 82, 631-636.

Dieleman, S.J., Bevers, M.M., Poortman, H. \& van Tol, H.J.M. (1983) Steroid and pituitary hormone concentrations in the fluid of preovulatory bovine follicles relative to the peak of $\mathrm{LH}$ in the peripheral blood. J. Reprod. Fert. 69, 641-650.

Dorrington, J.H., Moon, Y.S. \& Armstrong, J.T. (1975) Estradiol- $17 \beta$ biosynthesis in cultured granulosa cells from hypophysectomized immature rats; stimulation by follicle-stimulating hormone. Endocrinology 97, 1328-1331.

Dott, H.M., Hay, M.F., Cran, D.G. \& Moor, R.M. (1979) Effect of exogenous gonadotrophin (PMSG) on the antral follicle population in the sheep. $J$. Reprod. Fert. 56, 683-689.

Elsden, R.P., Nelson, L.D. \& Seidel, G.E., Jr (1978) Superovulating cows with follicle-stimulating hormone and pregnant mares serum gonadotropin. Theriogenology 9, 17-26.

Gibb, M., Thurley, D.C. \& McNatty, K.P. (1981) Active immunization of Romney ewes with an androstenedione-protein conjugate. Effect on oestrus and ovulation rate. N.Z. Jl agric. Res. 24, 5-9.

Greenwald, G.S. (1962) Analysis of superovulation in the adult hamster. Endocrinology 71, 378-389.

Henderson, K.M. \& Franchimont, P. (1981) Regulation of inhibin production by bovine ovarian cells in vitro. J. Reprod. Fert. 63, 431-442.

Hirshfield, A.N. (1979) The role of FSH in the recruitment of large follicles. In Ovarian Follicular Development and Function, pp. 19-22. Eds A. R. Midgley Jr \& W. A. Sadler. Raven Press, New York.

Lablou-Kassi, A., Schams, D. \& Glatzel, P. (1984)
Plasma gonadotrophin concentrations during the oestrous cycle and after ovariectomy in two breeds of sheep with low and high fecundity. J. Reprod. Fert. 70, 165-173.

Laster, D.B. (1973) Ovulation, fertility and prenatal mortality in heifers treated with PMSG or porcine FSH. J. Reprod. Fert. 33, 275-282.

McLachlan, R.I., Colvin, N., Quigg, H., Burger, H. \& Lee, V.W.K. (1984) Apparent specific FSH stimulation activity of human ovarian follicular fluid. Proc. Endocrine Soc. Aust. 27, Abstr. 68.

McNatty, K.P. (1981) Ovarian follicular development from the onset of luteal regression in humans and sheep. In Follicular Maturation and Ovulation, pp. 1-18. Ed. R. Rolland, E. V. van Hall, S. G. Hillier, K. P. McNatty \& J. Schoemaker. Excerpta Medica, Amsterdam.

McNatty, K.P., Dobson, C., Gibb, M., Kieboom, L.E. \& Thurley, D.C. (1981) Accumulation of luteinizing hormone, oestradiol and androstenedione by sheep ovarian follicles in vivo. J. Endocr. 91, 99-109.

McNatty, K.P., Gibb, M., Dobson, C., Ball, K., Coster, J., Heath, D. \& Thurley, D.C. (1982) Preovulatory follicular development in sheep treated with PMSG and/or prostaglandin. J. Reprod. Fert. 65, 111-123.

McNatty, K.P., Hudson, N., Henderson, K.M., Lun, S., Heath, D.A., Gibb, M., Ball, K., McDiarmid, J.M. \& Thurley, D.C. (1984) Changes in gonadotrophin secretion and ovarian antral follicular activity in seasonally breeding sheep throughout the year. $J$. Reprod. Fert. 70, 309-321.

McNatty, K.P., Henderson, K.M., Lun, S., Heath, D.A., Ball, K., Hudson, N.L., Fannin, J., Gibb, M., Kieboom, L.E. \& Smith, P. (1985) Ovarian activity in Booroola $\times$ Romney ewes which have a major gene influencing their ovulation rate. J. Reprod. Fert. $\mathbf{7 3}$, 109-120.

McNeilly, A.S. (1984) Changes in FSH and the pulsatile secretion of LH during the delay in oestrus induced by treatment of ewes with bovine follicular fluid. $J$. Reprod. Fert. 72, 165-172.

Monniaux, D., Chupin, D. \& Saumande, J. (1983) Superovulatory responses in cattle. Theriogenology 19, 55-99.

Peters, H. \& McNatty, K.P. (1981) Ovulation. In The Ovary: a Correlation between Structure and Function, pp. 75-79. Granada Press, London.

Peters, H., Byskov, A.G., Himelstein-Braw, R. \& Faber, 
M. (1975) Follicular growth: the basic event in the mouse and human ovary. $J$. Reprod. Fert. 45, $559-566$.

Richards, J.S. (1980) Maturation of ovarian follicles: actions and interactions of pituitary and ovarian hormones on follicular cell differentiation. Physiol. Rev. 60, 51-89.

Ross, G.T., Cargille, C.M., Lipsett, M.B., Rayford, P.L., Marshall, J.R., Strott, C.A. \& Rodbard, D. (1970) Pituitary and gonadal hormones in women during spontaneous and induced ovulatory cycles. Recent Prog. Horm. Res. 26, 1-62.

Scaramuzzi, R.J. \& Radford, H.M. (1983) Factors regulating ovulation rate in the ewe. J. Reprod. Fert. 69, 353-367.

Schams, D., Menzer, Ch., Schallenberger, E., Hofiman, B., Han, J. \& Hahn, R. (1978) The use of pregnant mare serum gonadotrophin (PMSG) and endocrine response in cattle. In Control of Reproduction in the Cow, pp. 122-143. Ed. J. M. Sreenan. M. Nijhoff, The Hague.

Stouffer, R.L., Coensgen, J.L., di Zerega, G.S. \& Hodgen, G.D. (1981) Induction of defective corpus luteum function by administration of follicular fluid to monkeys during the follicular phase of the menstrual cycle. In Dynamics of Ovarian Function, pp. 185-190. Eds N. Schwartz \& M. HunzickerDunn. Raven Press, New York.

Tsafriri, A. \& Braw, R.H. (1984) Experimental approaches to atresia in mammals. In Oxford Reviews of Reproductive Biology 6, 226-265. Oxford University Press.

Wright, R.W., Jr, Bondioli, K., Grammer, J., Kuzan, F. \& Menino, A., Jr (1981) FSH or FSH plus LH superovulation in ewes following estrus synchronization with medroxyprogesterone acetate pessaries. J. Anim. Sci. 52, 115-118.

Zeleznik, A.J. (1981) Factors governing the selection of the preovulatory follicle in the Rhesus monkey. In Follicular Maturation and Ovulation, pp. 37-50. Eds R. Rolland, E. V. van Hall, S. G. Hillier, K. P. McNatty \& J. Schoemaker. Excerpta Medica, Amsterdam. 